Zofia Sawaniewska-Mochowa (1)

Instytut Slawistyki Polskiej Akademii Nauk, Warszawa

zofia.sawaniewska-moch@ispan.waw.pl

Małgorzata Kasner

Instytut Slawistyki Polskiej Akademii Nauk, Warszawa

malgorzata.kasner@ispan.waw.pl

\title{
WARIANCJE SEMANTYCZNE POJĘCIA KOLTUNA W WYBRANYCH TEKSTACH KULTURY POLSKIEJ I LITEWSKIEJ ${ }^{1}$
}

Słowa klucze: kołtun, pojęcie kulturowe, derywacja semantyczna, język polski, język litewski, teksty kultury

Keywords: kołtun 'Polish Plait', cultural concept, semantic derivation, Polish, Lithuanian, texts of culture

Pojęcie wariancji rozumianej jako przeciwieństwo standaryzacji nie było dotychczas jakoś szczególnie eksponowane w badaniach językowo-kulturowych, ukierunkowanych na poznanie procesów myślowych człowieka i sposobów konceptualizowania świata przez użytkowników danego języka. Pozornie może się wydawać, że uwzględnianie w opisie językowo-kulturowego obrazu pojęć wariantywności odzwierciedlającej się na płaszczyźnie pragmatycznej nie wniesie specjalnie nowych treści do rozumienia struktury semantycznej nazw. Tymczasem Jerzy Bartmiński (2006a: 13) jednoznacznie sprzeciwia się izolowaniu od siebie w rekonstrukcjach pojęć „różnych poziomów organizacji języka” i domaga się łącznego uwzględniania zarówno gramatyki, jak i leksyki, nazw podstawowych, jak i derywatów od nich, form językowych w całej sieci systemowych relacji, jak i w ich konwencjonalnych użyciach.

1 Zaangażowanie autorek w przygotowanie tego artykułu jest równe i wynosi po 50\%. 
W rekonstrukcjach pojemności i transformacji znaczeń pojęć kulturowych, często nacechowanych aksjologicznie, najcenniejszą podstawę materiałową stanowią teksty kultury wytworzone w różnych epokach, stylach, konwencjach. Termin tekst kultury rozumiemy, zgodnie z koncepcją semiotyczną Jurija Łotmana i Borisa Uspienskiego (1977: 156), jako „realizację kultury”. Funkcją każdego tekstu kultury (niezależnie, czy jest zbudowany ze znaków jednego kodu, czy wielu kodów) jest przenoszenie „jakichś treści kulturowych” (Żegleń 2000: 228).

Metodą dominującą w naszych badaniach jest analiza werbalnych tekstów kultury, w których pojawiają się słowa kołtun, lit. kaltūnas i wyrazy oraz wyrażenia pochodne od nich. Jako uzupełnienie bazy materiałowej wykorzystujemy dane systemowe czerpane ze słowników języka polskiego i litewskiego. Nieprzypadkowo wybrałyśmy jako podstawę do prowadzenia dociekań językowo-kulturowych nad wariancją struktury semantycznej pojęcie коŁTuna (łac. plica polonica), oznaczające niegdyś 'zbity, spilśniony kłąb włosów na głowie, będący objawem tajemniczej choroby'. Zjawisko to, opisywane przez medyków europejskich od 1325 r. i dyskutowane co do jego przyczyn aż po 1877 r., nierzadkie jeszcze w XIX w. (zwłaszcza na wschodnich obszarach Polski, a nawet spotykane w pierwszej połowie XX w. (SEBań I: 763)), dziś już nie istnieje, jednak wciąż pozostaje, co postaramy się udokumentować w języku polskim i litewskim, elementem społecznie utrwalonej wiedzy o świecie, wykorzystywanym w różnych typach dyskursów do komunikowania bogatych znaczeń, dosłownych i metaforycznych. Interesuje nas zatem pojemność znaczeniowa pojęcia związanego niegdyś ze sferą choroby, wierzeń i praktyk magicznych oraz jego transformacje semantyczne i stylistyczne w różnych tekstach (od minimalnych po bardzo rozbudowane). Sięganie do tekstów (dziś bardzo ułatwione dzięki istnieniu korpusów i wyszukiwarek, z czego skrzętnie skorzystałyśmy) przybliża nas do realnej praktyki językowej i pozwala odkrywać zmieniające się sensy pojęć kulturowych w różnych kontekstach, adekwatne do ich bogatej natury ${ }^{2}$.

2 Nie zajmujemy się w tym artykule szczegółowo kwestiami etymologicznymi i chronologicznymi, choć nie podlega dyskusji, że uwzględnianie tego typu danych w całościowej rekonstrukcji pojęcia czy konceptu jest jak najbardziej uzasadnione. Informacje etymologiczne i źródła historyczne zostały stosunkowo obszernie uwzględnione w językowo-kulturowym opisie kołtuna jako choroby w opracowaniu Marzeny Marczewskiej (2012: 113-119), dlatego ograniczamy się do przywołania w tym miejscu tylko tych danych, które są najczęściej wskazywane w słownikach etymologicznych języka polskiego. Nazwa kołtun, obecna w polszczyźnie od XVI w., interpretowana jest jako zapożyczenie z języków ruskich (SEBr: 248). Z ukr. kovtún 'kołtun' < psł. dial. “kl tunz 'ts.' < psł. dial. *klatati 'poruszać się, kołysać, chwiać' wywodzi SEBor: 246, por. dial. kiełtać $\|$ kiełdać 'chwiać, ruszać, mieszać'; kiełtać się 'chwiać się, kołysać się’ (ibid.); por. ros. kołtún 'choroba włosów; kołtun', dial. też przezwisko; kółty 'zagmatwane sprawy, kłopoty, troski, plotki’; błr. kaŭtún, też 'kudły, splątane, pogmatwane włosy’ (SESł IV: 375-376). 


\section{Kołtun w polskich tekstach kultury}

Bezpośrednią inspiracją do podjęcia wspólnych rozważań na temat semantyki ko€TUNA przez językoznawcę i kulturoznawcę stał się tekst literacki - intrygująca opowieść ze zbioru Opowiadania bizarne Olgi Tokarczuk (2018), zatytułowana Zielone dzieci, czyli opis dziwnych zdarzeń na Wolyniu sporządzony przez medyka Jego Królewskiej Mości Jana Kazimierza, Williama Davissona. Ta kreacja literacka kołtuna jako zjawiska bizarnego (fr. bizarre 'dziwny, niezwykły, upiorny, także śmieszny') uświadamia, jak bardzo starali się rozpoznać jego tajemniczą naturę dawni medycy, jak różne odniesienia mitologiczne i magiczne skrywało w sobie to pojęcie wiązane $\mathrm{w}$ dawnych kulturach $\mathrm{z}$ chorobą.

Owa przypadłość znana jest pod wieloma nazwami w całej Europie. We Francji bywa może najrzadsza, ludzie tam bowiem przywiązują wielką wagę do swojego wyglądu i trefią nieustannie włosy. W Niemczech plica polonica występuje jako mahrenlocke albo alpzopf czy drutenzopf. Wiem, że w Danii mówi się o nim marenlok, w Walii i Anglii zaś elvish knot. Kiedym jednego razu jechał przez Dolną Saksonię, słyszałem, że nazywali takie włosy selkensteert. W Szkocji uważa się, że jest to starożytna fryzura dawnych pogan żyjących w Europie, częsta u plemion druidzkich. Czytałem także, że za początek plica polonica w Europie uważa się najazd Tatarów na Polskę pod rządami Leszka Czarnego. Istniały też przypuszczenia, że moda ta przywędrowała aż z Indii. Spotkałem się nawet $\mathrm{z}$ ideą, że to Hebrajczycy pierwsi wprowadzili zwyczaj splątywania włosów w sfilcowane strąki. Nazer mówiło się o świętym mężu, który ślubował nie obcinać nigdy włosów dla chwały Bożej. Taka liczba sprzecznych teorii i biały śnieżny bezkres sprawiły, że najpierw pogrążony w umysłowym otępieniu, popadłem w końcu w twórcze podniecenie i badałem plica polonica w każdej wsi, którą mijaliśmy (ibid.: 13-14).

W Dziennikach Michała Römera pod datą 9 (22) IV 1911 r. jest wpis omawiający zawartość rękopiśmiennych ksiąg lekarskich pozostawionych przez jego prababkę ze strony matki, Różę Bohdanowiczową (180o-1879). Komentując znachorskie praktyki lekarskie prababki, Römer pisze:

Pierwotna ludowa sztuka lekarska, czyli znachorstwo, posiada cechy obrzędowe, religijne; jest to metafizyka. Choroby mają tam swoją indywidualność, swoje odrębne tajemnicze życie; są to jakieś istoty złośliwe, jakieś potęgi wrogie, które mają swoją naturę, swój byt metafizyczny. Sztuka lekarska polega na zamawianiu ich, na zwalczaniu ich potęgi. W księgach prababki takie usposobienie chorób jest jeszcze chwilami widoczne; rozmaite „kołtuny”, „humory” itd. są jakby duchami, złośliwymi bożkami pogańskimi (Römer 2017: 102-103).

Choroba objawiająca się skłębionymi, skręconymi, zbitymi włosami na głowie była rozpowszechniona, jak sugerowałaby choćby nazwa łacińska plica polonica czy określenie kołtun polski, warkocz nadwiślański, w Polsce, ale zjawisko występowało 
też na innych obszarach kulturowych, zwłaszcza w kręgu germańskim³ ${ }^{3}$ tylko pod innymi nazwami, wykazującymi paralele i identyczności 'kołtuna' z nazwami istot mitycznych, koboldów, elfów, skrzatów, wywołujących skołtunienie włosów u ludzi i zwierząt. Bogatą dokumentację na temat określeń, które pojawiły się już w cytowanej wyżej opowieści siedemnastowiecznego medyka Davissona (Tokarczuk 2018), znajdujemy pod hasłem der Weichselzopf w dziewiętnastowiecznych słownikach niemieckich Johanna Adelunga (1811: 1446) ${ }^{4}$ czy Konrada Schwencka (1838: 765) ${ }^{5}$ oraz Jacoba i Wilhelma Grimmów (DW XXVIII: 537), także w Deutsche Mythologie Jacoba Grimma (1835: 262) ${ }^{6}$. Dysponujemy ponadto obszernym językowo-kulturowym studium Marzeny Marczewskiej (2012: 113-147), ukazującym semantykę kołtuna w polszczyźnie i kulturze ludowej jako choroby, której pochodzenie i pozbywanie się ściśle wiązało się z systemami wierzeniowymi i ludowymi praktykami magicznymi. Kołtun w konceptualizacji ludowej łączył w sobie złe i dobre moce. Z jednej strony silne było przekonanie, że chorobę zadawały czarownice, demony, zmory, że mogła ona być karą za popełnione grzechy, z drugiej zaś wierzono w dobroczynne właściwości kołtuna, sądząc, że jest on sposobem na pozbycie się różnych chorób wewnętrznych,

3 Zygmunt Gloger w Encyklopedii staropolskiej wyraził pogląd, „iż zjawisko kołtunem zwane od wieków było znane u Germanów, nad Renem, w Bawaryi itd., i z zachodu na wschód, a nie odwrotnie się rozprzestrzeniało" (Gloger 1978: 63).

4 „Weichselzopf, nazwa kołtuna włosów w różnych miejscach ciała, zwłaszcza na głowie, którego nie można rozplątać i który powstaje na skutek zepsutych i nieczystych soków. Epidemicznie szerzy się zwłaszcza w Polsce, w Chanacie Krymskim i na Węgrzech i jest nazywany także Judenzopf 'warkoczem żydowskim', ponieważ często występuje u Żydów żyjących w tych krajach, jednak z braku wiedzy jego nazwę wywodzi się od wieszczycy albo zmory, stąd też zwany jest Alpzopf, Alpklatte, Mahrenklatte (w szwedzkim Martofva), w Dolnej Saksonii Elsklatte, w gwarze hanowerskiej Sellkensteert. [...] Ponieważ choroba ta bardzo często występuje w Polsce (dlatego też po łacinie nazywa się trica polonica), to pochodzenie słowa od nazwy rzeki Wisły nie byłoby nieprawdopodobne. Jednakże ponieważ słowo to w wielu regionach brzmi Wichtelzopf [...], jego źródłem może być także Wicht 'krasnal, skrzat', gdyż niegdyś słowo to oznaczało złego ducha, i wówczas miałoby takie samo znaczenie co Altzopf i Mahrenklatte" (tłum. z niemieckiego Katarzyny Siewert-Kowalkowskiej).

5 W tym źródle pod hasłem der Weichselzopf (dosł. 'warkocz znad Wisły' lub 'warkocz nadwiślański', łac. Plica polonica, pol. kołtun polski) powtórzone zostały wymienione już w słowniku Adelunga określenia 'kołtuna' w językach germańskich, konceptualizowanego w wyobrażeniach ludowych jako warkocz, za którego powstanie winą obarczano wrogie człowiekowi istoty, takie jak zmora, wieszczyca, skrzaty, krasnale, elfy. Wyraz hasłowy Weichselzopf nie pochodzi od Weichsel 'Wisła', lecz powstał najprawdopodobniej na skutek przekształcenia nazwy Wichtelzopf 'warkocz skrzata' (zob. Gloger 1978: 63).

6 „[...] jeśli wieszczyca, zmora nocna plączą włosy ludzi, grzywę i ogon koni w supły: alpzopf, drutenzopf, wichtelzopf, weichselzopf (od tego później jeszcze), w Dolnej Saksonii mahrenlocke, elfklatte [...], ang. elflocks [...], elvish knots, czasownik elf znaczy u Shakspeare'a 'skołtunić włosy': "elf al my hair in knots« Lear 2, 3. Także litewski duch, zwany aitwaras, kołtuni włosy. W kilku regionach Dolnej Saksonii leżących między Łabą i Wezerą wichtelzopf nazywa się selkensteert [...] sellentost (Hufelands Journal 11, 43), co rozumiem: warkocz ducha domowego, zwanego gesellchen" (tłum. z niemieckiego K. Siewert-Kowalkowskiej). 
np. gośćca. W kołtunie lokowały się bowiem różne dolegliwości i wraz z usunięciem skołtunionych włosów ginęły. Aby zabieg był skuteczny, należało go wykonać gorącym żelazem lub dwoma kamieniami wczesnym rankiem w Niedzielę Wielkanocną. Obcięty kołtun trzeba było zakopać, np. pod rynną, lub zniszczyć (Łopatyńska 2013). Nosiciele kołtuna często jednak wzbraniali się przed jego usunięciem, obawiając się, że sprowadzi to na nich groźne choroby, a nawet śmierć (najgroźniejszy był kottun zagniewany, uważany za chorobę śmiertelną (SKarł II: 409)). Dlatego zjawisko „hodowania” kołtuna w celach leczniczych, mające silne umocowanie w myśleniu magiczno-mitycznym, utrzymywało się według danych etnografów jeszcze reliktalnie w Polsce w latach 60. XX w. (por. Łopatyńska 2013). Zadawaniu kołtuna służyły rytuały werbalne (akty performatywne), wypowiadane we właściwym kontekście sytuacyjnym, wywołujące skutki w postaci choroby: Zadaję Janowi (Stachowi itp.) kołtona, bołtona, łamiacego, bolacego na rok i sześć niedziel (SKarł II: 409, za Michałem Federowskim z okolic Siewierza i Pilicy). Dla takich rytuałów „stwarzających” Anna Engelking (2000) proponuje eksplikację 'mówiąc to, powoduję, że tak się staje’. Kołtuna mogły sprowadzić na kogoś osoby uważane w społeczności wiejskiej za czarownice, które za pomocą słów, także gestów i rekwizytów, uaktywniały złą moc, wywołującą chorobę: [Czarownica, czyli ciota], gdy chce dziecku szkodzić, odzywa się do niego lub myśli sobie te wyrazy: „Bodaj cię kołtun skręcił” (K3Kuj: 98). Odczynianiu kołtuna zadanego przez czarownicę również służyły rytuały werbalne, zamowy, które, wypowiadane przez znachorów, miały zażegnać działanie złych mocy, np.: Święty Benonie, idź precz kołtonie! (należało tę formułę powtórzyć 3 razy, ibid.: 95)

Rozumienie kołtuna jako choroby o tajemniczym pochodzeniu jest już we współczesnej kulturze zapomniane, chyba że mamy do czynienia z konceptualizacjami literackimi (tak jak w przywołanym opowiadaniu O. Tokarczuk), które osadzają to pojęcie w kontekście magiczno-mitologicznym, lub z dyskursem specjalistycznym (etnograficznym lub medycznym) na temat praktyk lecznictwa ludowego. Ślad magicznego myślenia o kołtunie odzwierciedlił się w danych frazeologicznych: kołtuna mieć na co 'mieć chęć, zachciewać się': chłop ma kołtuna na gorzałkę (SEBr: 248; SKarł II: 409); zażegnać komuś kottuna 'zbić kogoś' (SF I: 336). U podstaw podanych frazeologizmów, dziś już należących do archiwum języka polskiego, legło przeświadczenie o przyczynach choroby (kołtun pojawi się, jeśli nie zaspokoi się chęci na coś) i jej pozbywaniu się za pomocą działań magicznych.

Sama nazwa ma wciąż znaczną frekwencję tekstową, co ustaliłyśmy na podstawie Narodowego Korpusu Języka Polskiego (NKJP), posługując się wyszukiwarką PELCRA. Dla podstawowego hasła KOŁTUn zarejestrowano: 731 akapitów, zawierających 793 przykłady użyć z 549 różnych tekstów. Najliczniej reprezentowane są konteksty użyć ze źródeł publicystycznych (dzienników i tygodników) i internetowych (fora, czaty), mniej jest poświadczeń z tekstów literackich (30 akapitów).

7 Rytuały werbalne i niewerbalne służące zdejmowaniu kołtuna omówiła na bogatym materiale M. Marczewska (2012: 147-149). 
Cytaty wyekscerpowane z korpusu dokumentują nadal obecność w komunikacji nazwy kołtun i lm. kołtuny w znaczeniu ‘splątane włosy na głowie’. Do zasobu potocznego weszły liczne formy utworzone od podstawy kołtun, informujące o wyglądzie zaniedbanej fryzury człowieka, także o uwłosieniu, sierści zwierzęcia, głównie psa. Derywaty przymiotnikowe kołtuniasty i kołtunowaty odnoszą się do włosów brudnych, rozczochranych, poplątanych i zazwyczaj występują w połączeniach kołtuniasta, kołtunowata czupryna; kołtuniasta grzywa (USJP II: 377); kołtunowate włosy (WSJP PAN). Czasowniki kołtunić (się), kołtunieć oddają zjawisko zwijania się, skręcania się, zbijania się włosów (USJP II: 377). Nawiązanie do dawnego desygnatu 'spilśniony kłąb włosów na głowie' jest czytelne, ale sens pojęcia już zmodyfikowany. Kołtun na głowie nie jest już rozumiany jako objaw tajemniczej choroby i nie kojarzy się go z magią, lecz z niskim poziomem higieny i zaniedbywaniem podstawowych zabiegów pielęgnujących włosy. Kołtunem nazywa się w tekstach literackich i publicystycznych 'brudne, sterczące, posklejane włosy', niezależnie, czy mowa jest o włosach zlepionych/sklejonych krwią, potem, czy splątanych z jakiegokolwiek innego powodu, jak to dokumentują swobodne wypowiedzi internautek (pisownia oryginalna):

Dzisiaj może poćwicze, chociaż powątpiewam w to. Nawet nie chciało mi sie rano iść pod prysznic. Śmierdze, mam kołtuny na głowie, ale dobrze jest (NKJP: Co Dziś Dla Siebie Zrobiłaś/-eś?, www.forumowisko.pl, 19 II 2006).

motylek: Ja mam taka fryzurke jak Anka Mucha... no tylko trochę dłuższe włoski i mam takie szczęście, że dobrze mi sę układają, sa proste i nie musze modelować

...Poranna... Kaffcia...: Ja też. Tylko rano trzeba przeczesać bo po nocy sa kołtuny, a strasznie tego nie lubię, o nie.

motylek: Ja też miałam lekkie kołtunki, ale teraz kupiłam sobie odżywkę $z$ Avonu do włosów blond i wogóle mi się nie kołtunią (NKJP: Pomóżcie! Jak się obciąć?, www.forumowisko.pl, 12 XII 2005).

Pojęcie KoŁTuna może być przenoszone z 'poskręcanych, sterczących, rozczochranych włosów' na wszystko, co jest 'splątane', 'pogmatwane', 'zbite w kłąb', 'trudne do pozbycia się'. Kołtun jako metafora czy komponent metafor potocznych bardzo obrazowo oddaje różne aspekty rzeczywistości:

kołtun 'poskręcane, zbite w jeden kłąb gałęzie drzew'; 'kłopot osobisty, trudny do pozbycia się' (SKarł II: 409, z Augustowszczyzny);

kołtun kurzu (NKJP: M. Tulli, Tryby, Warszawa 2003);

chmury w kołtun czesane (NKJP: A. Pankowski, Ksiadz Helena - wybór utworów dramatycznych, Kraków 1996); 
Na ziemi sieć torów, nad głowa sieć drutów, splątana w wielki kołtun. Druciany mózg (NKJP: A. Bobkowski, Szkice piórkiem: Francja 1940-1944, Paryż 1957); kołtuny konceptów 'zawiłości stylu' (SEBań I: 763, z Wacława Potockiego); [...] w głowie i sercu miała jakoby ten kołtun zwity zmyśleń przeróżnych a strachań niemałych (NKJP: W. Reymont, Chłopi, Warszawa 1909).

Najważniejszą zmianą semantyczną, jaka dokonała się w strukturze pojęcia KoŁTUN, jest przeniesienie jądra znaczeniowego z 'choroby', 'splotu włosów na głowie' na człowieka nazywanego kołtunem ze względu na wygląd 'człowiek z kołtunem na głowie', 'człowiek o rozczochranych, zmierzwionych włosach' (dziś już dialektalne), jak i na cechy mentalne i etyczne.

W XIX w. są rejestrowane użycia świadczące o funkcjonowaniu kołtuna jako przezwiska mieszczanina lub ubogiego szlachcica: Szlachcic na jednym dworku, jak i mieszczuch obdarzany między swemi bywa przydomkiem kołtun (SKarł II: 409, z Łęczyckiego), ekspresywny aspekt przezwiskowego określenia kołtun eksponują też teksty folkloru: Obiecywałeś mi karetę $i$ konie / żeby ja przystała do ciebie, kołtonie (ibid., za Kolbergiem, pieśń z Łęczyckiego), Mazewskie dziewczęta to same kołtony (ibid.); wypowiadane w gniewie złorzeczenie: $t$, osiemnasty kołtunie! (K11Poz3: 120).

Nie można w opisie pojemności semantycznej badanego pojęcia kulturowego pominąć faktu, że kołtun funkcjonuje też w polszczyźnie jako nazwa własna osoby, zarówno jako nazwisko, służące identyfikacji jego nosiciela, jak i antroponim literacki, wykreowany przez autora utworu w celu charakteryzacji postaci. W świetle Słownika nazwisk wspótcześnie w Polsce używanych Kazimierza Rymuta (SN V: 93-94) nazwisko Kołtun nosi 2689 osób, Kołton - 1012, Kołtuniak - 743, Kołtunik 220, pomijamy formy derywowane mniej liczne. Kołtun jako nazwisko, czyli „znak” identyfikujący konkretną osobę, dokumentują również teksty urzędowe i prasowe, relacjonujące zdarzenia z udziałem konkretnych postaci, np.: Czyżby minister Kołtun bat się ujawnić, o ile wzrosna wydatki na bardzo liczne i dalekie podróże zagraniczne marszałka Senatu Adama Struzika? (6 tys. złotych dla posła, „Gazeta Wyborcza", 27 XI 1996). Stosunkowo liczne w świetle danych NKJP użycia antroponimu Kołtun w przekazach prasowych mogą dowodzić, że pewien składnik rzeczywistości (kołtun) stanowił na tyle wyróżniającą cechę niektórych osób, że stał się kiedyś podstawą motywacyjną nazwisk.

Odniesienia do kołtuna w sensie dosłownym czy symbolicznym motywują również wykorzystanie nazwy osobowej Kołtun w tekstach literackich, co pozostaje $\mathrm{w}$ ścisłym związku z przyjętą przez autora kreacją świata przedstawionego i sposobem charakteryzowania postaci przez nadawanie im nazwisk (przezwisk) znaczących. Nieprzypadkowo tak nazywani bohaterowie pochodzą z niższych warstw społecznych, chłopstwa czy mieszczaństwa (jak w powieściach Adolfa Dygasińskiego). Przezwisko Kołtun noszą też w literaturze fantasy postaci o dziwnym 
usposobieniu i wyglądzie (mające skołtunione, posklejane włosy), czego przykładem jest twórczość Andrzeja Sapkowskiego.

Najsilniej odzwierciedla się obecnie w różnych typach danych (systemowych, tekstowych) negatywnie wartościowane rozumienie kołtuna jako 'człowieka zacofanego, ograniczonego intelektualnie, także zachowawczego i nietolerancyjnego'. Pogardliwy stosunek do ludzi, nisko ocenianych z punktu widzenia takich cech, jak intelekt, wola, postawa wobec świata, społeczeństwa, życia, oddają liczne derywaty słowotwórcze tworzone od podstawy kołtun:

kołtunka 'kobieta zacofana, ograniczona intelektualnie, filisterka': Gdy feministka styszy taką kobietę, uważa ja za zaściankowa kottunkę (cyt. za: WSJP PAN);

kołtuński 'charakterystyczny dla kołtuna - człowieka ograniczonego, mającego wąskie horyzonty intelektualne’: Urna wyborcza stopniowo zacznie wynosić ugrupowania nacjonalistyczno-klerykalne, ksenofobiczne i kołtuńskie (cyt. za: WSJP PAN);

kołtuńsko przysłówek od kołtuński (USJP II: 377): postępować, myśleć kołtuńsko (https://polish.enacademic.com/24486/kołtuńsko, dostęp: 8 II 2020);

kołtunowaty 'trochę ograniczony i mający dość wąskie horyzonty intelektualne’: Jednego kołtunowatego filozofa już tu mieliśmy kiedyś, widać teraz pojawit się jeszcze lepszy ignorant (cyt za: WSJP PAN); kołtunowate poglady (USJP II: $377)$;

kołtunieć 'stawać się kołtunem, obskurantem, człowiekiem ciemnym, zacofanym' (ibid.);

kołtuństwo 'postawa ludzi ograniczonych i mających wąskie horyzonty intelektualne; także grupa ludzi prezentujących taką postawę’: Wydawało się, że nic nie powstrzyma kołtuństwa i głupoty władz od kultury (cyt. za: WSJP PAN); Boja się, że zostana zaklasyfikowani do nienowoczesnych, do kottuństwa, do ciemnogrodu (ibid.);

kołtuneria 'umysłowość i moralność ludzi ograniczonych, mających wąskie horyzonty intelektualne'; również 'zespół, grupa ludzi o zacofanych, nietolerancyjnych poglądach' (USJP II: 377); Tę cała koalicję trzeba przegonić na Białoruś. Kołtuneria Dulskich, bałwanów zaściankowych (cyt. za: WSJP PAN).

Połączenia stabilizowane typu kołtun parafialny, prowincjonalny (SF I: 336), zaściankowy, drobnomieszczański; obłudny kołtun; kołtuńskie obyczaje, stosunki, opinie; drobnomieszczańskie kołtuny czy kołtuneria drobnomieszczańska (USJP II: 377) wzmacniają asocjacje z zacofaniem, hipokryzją, ograniczeniem intelektualnym i nietolerancją.

Kołtun stał się jako pojęcie aksjologiczne swoistym narzędziem w sporach ideologicznych i politycznych, etykietującym i dyskredytującym przeciwnika (indywi- 
dualnego lub zbiorowego), który prezentuje inny światopogląd i odmienną hierarchię wartości niż nadawca. Nieprzypadkowo w tym wartościującym negatywnie znaczeniu kołtun występował w tekstach utrzymanych w poetyce socrealistycznej, żeby piętnować ciasnotę umysłową mieszczaństwa i zachowawczość ludzi niechętnych ideologii komunistycznej:

Polewka, ogarnięty nienawiścią do krakowskiej kołtunerii, głosił m.in.: „Dziś martwi się kołtun, że Nowa Huta będzie zadymiać miasto i że okopci stare, czcigodne mury. Taką troskę sobie wymyślili na fali westchnień za dawnymi »dobrymi« czasami i w trwodze o mieszkanie, gdzie miejsce martwych gratów zajmują nowi, żywi i twórczy ludzie" (NKJP: T. Torańska, Oni, Warszawa 1985).

Od używania nacechowanego określenia kołtun nie stroni też współczesna publicystyka ${ }^{8}$, przypomniane zostało nawet zabawnie już dziś brzmiące wyrażenie kołtun latawczy, zastosowane niegdyś przez Ludwika Krzywickiego wobec kategorii umysłowej ludzi „Zwolnionych z obowiązku krytycyzmu i zawstydzenia” (NKJP: felieton K.T. Toeplitza, Mój wybór - rzeczy mniejsze, Warszawa 1998).

Kołtun, często w kolokacji prostak i kołtun, pojawia się na różnych forach internetowych w toczonych przez internautów (czasami w sposób bardzo wulgarny) dyskusjach na temat historii, religii i zachowań konkretnych polityków:

Więc się pytam, a jak w odpowiedzi masz rzucać inwektywami jak byle prostak i kołtun to jest to zniżenie się poziomem do kilku prostaków którzy tutaj uprawiają sobie uliczne pyskówki (NKJP: „pytariusz”, Usenet-pl.soc.polityka, 28 IX 2006, zapis oryginalny).

Termin plica polonica stał się nawet ostatnio inspiracją dla satyryków i felietonistów do rozważań nad esencją polskości:

[...] bodaj nie ma żadnego polskiego zjawiska czy produktu, który miałby tak dostojną łacińską nazwę. [...] I każdy Polak ma prawo do kołtuna. Jeśli nie realnego, to mentalnego'.

Immanentną cechą tekstów satyrycznych jest przerysowywanie pewnych cech stereotypowych, przypisywanych różnym narodom czy grupom społecznym, i przezwyciężanie ich ironią (autoironią), humorem i śmiechem (Bartmiński 2009: 110). Jednak kołtun jako polski kulturem ${ }^{10}$, przywołany przez podmiot mówiący nawet $\mathrm{w}$ formie dowcipnej językowo, nie trafia jednakowo do odbiorców, jednych bawi,

8 Zob. cytaty z tekstów publicystycznych ilustrujące hasło kołtun w znaczeniu 'człowiek ograniczony, o wąskich horyzontach intelektualnych' w WSJP PAN.

9 Zob. felieton Plica polonica Ludwika Stommy („Polityka” 2018, nr 19 (3159), s. 96).

10 Kołtun w rozumieniu 'postawa życiowa' został zaliczony do polskich kulturemów przez Alicję Nagórko (2004: 28-29). Badaczka włącza do tej kategorii nie tylko słowa o pozytywnych konotacjach, ale też, podobnie jak kołtun, wartościujące negatywnie, np. cham, cwaniak czy warchoł. 
innych oburza do tego stopnia, że składają doniesienie w sądzie i domagają się kary dla satyryka za obrazę narodu polskiego z powodu użycia określenia kołtuński kraj ${ }^{11}$. Na tym właśnie polega wariancja semantyki pojęcia kulturowego, że trzeba je odczytywać w zależności od punktu widzenia nadawcy i odbiorcy tekstu, ich wiedzy, doświadczenia, zasobów pamięci (które wcale nie muszą być zbieżne), skonwencjonalizowanych, przyjętych w danej epoce zachowań, wreszcie kontekstu sytuacyjnego ${ }^{12}$.

\section{Kołtun w litewskich tekstach kultury}

W opublikowanym w 1971 r. cyklu poetyckim Divertimento litewskie Josif Brodski przywołał dzieło osiemnastowiecznego włoskiego anatoma i medyka Stefana Lorenza Bisia (1724-180o?): Amicum philosophum de melancholia, mania et plica polonica. Bisio w latach 1763-1787 praktykował na Litwie ${ }^{13}$, gdzie dał się poznać nie tylko jako wybitny lekarz, ale także autor wielu prac naukowych z zakresu anatomii, neurologii i etiologii kołtuna. Kołtun był wówczas dość powszechny, o czym pisał Jędrzej Kitowicz (1728-1804): koltony lubo się znajdują w całej Polszcze i Litwie dosyć obfito (Widacka 2008: 1). Zacytowany przez Brodskiego traktat naukowy, którego pełny tytuł brzmi Responsum St. Bisii ad amicum philosophum de melancholia, mania et plica polonica suscitantem (Vilnae 1772) jest przechowywany w Bibliotece Uniwersytetu Wileńskiego i tam właśnie poeta zetknął się z nim po raz pierwszy. W części piątej swojego Divertimenta... Brodski napisał, inspirując się wymienionym traktatem: „Śliska od pomady / cząstka kobiety długie słowa wbija / w słuch, jak pięć palców w zawszone pokłady / włosów" (Brodski 2000: 53). I choć były to czasy, w których

11 Mowa o Antonim Szpaku, współtwórcy bydgoskiego kabaretu Klika, któremu groziła kara do 3 lat więzienia za użycie w felietonie na łamach „Angory” sformułowania „durny, kołtuński kraj” (por. M. Czarnecka, Satyryk, co naród znieważył, „Gazeta Wyborcza”, 18 V 2018, s. 3).

12 Punkt widzenia i perspektywa interpretacyjna to jedno z kluczowych narzędzi lubelskiej etnolingwistyki kognitywnej służące definiowaniu konceptów aksjologicznych jako tekstów kultury. Przez punkt widzenia Jerzy Bartmiński (2006b: 78) rozumie „czynnik podmiotowo-kulturowy, decydujący o sposobie mówienia o przedmiocie, w tym m.in. o kategoryzacji przedmiotu, o wyborze podstawy onomazjologicznej przy tworzeniu jego nazwy, o wyborze cech, które są o przedmiocie orzekane w konkretnych wypowiedziach i utrwalone w znaczeniu”, zaś „perspektywa rysuje się jako całościowy efekt ujmowania przedmiotu pod różnymi, uzupełniającymi się względami" (ibid.: 84). Problematyka punktu widzenia i perspektywy znalazła rozwinięcie w szeregu opracowań dotyczących instrumentarium JOS (zob. Bartmiński 2006b; Bartmiński, Niebrzegowska-Bartmińska 2006 oraz prace innych autorów w monografiach zbiorowych PWJK i PWTD poświęconych tym kategoriom).

13 Najpierw w posiadłościach magnackich, a później na Uniwersytecie Wileńskim, gdzie wykładał anatomię i fizjonomię. W $1770 \mathrm{r}$. pierwszy na Litwie przeprowadził sekcję zwłok w celach naukowych. Pierwszy dziekan Collegium Medicum Uniwersytetu Wileńskiego. W 1787 r. został oskarżony o herezję i wrócił do Włoch (Andriušis, Rimavičienè 2006: 17-25). 
już nikt raczej nie nazywał kołtuna chorobą, to w wierszu litewskiej poetki Nijole Miliauskaitė (1950-2002) kołtun (lit. kaltūnas) może nawet doprowadzić do śmierci:

gęstym kościanym grzebieniem / długo będzie czesać twoje włosy / mocno je zaplecie, zepnie / [...] żeby przypadkiem tylko kołtun / się nie wdał, żeby tylko życie / nie wyciekło, kropla po kropli [...] $]^{14}$ (Miliauskaité 1999: 446, tłum. Z.S.-M., M.K.).

Poetka nawiązuje tu do mitologicznego wyobrażenia kołtuna w litewskiej kulturze ludowej. Podobnie jak w polskim ludowym systemie wierzeniowym (por. Marczewska 2012: 134), na Litwie też funkcjowały wśród ludu wyobrażenia kołtuna jako istoty demonicznej, podstępnej, której usunięcie mogło sprowadzić na człowieka ślepotę, głuchotę, chorobę psychiczną, a nawet śmierć. Litewski historyk Aivas Ragauskas (2012: 1) nazwał nawet kołtuna fryzura narodową ${ }^{15}$. Jeszcze na początku XIX w. autorzy rozpraw medycznych na temat kołtuna opisywali go jako ciężką chorobę infekcyjną o konsekwencjach psychicznych i fizycznych (zob. Miežutavičiūtè 1991: 88). I chociaż dopiero w drugiej połowie XIX w. upowszechniło się traktowanie kołtuna jako efektu braku higieny, to także w XVIII w. pojawiali się światli medycy (chociażby przywoływany już S.L. Bisio), którzy nie ulegali zabobonom i przesądom na ten temat. Jako przykład A. Ragauskas podaje historię z 1787 r. o pewnym nieznanym $\mathrm{z}$ imienia wilnianinie, który jakoby z powodu kołtuna-choroby po pijanemu pobił mieszczanina. Sędziowie, przed którymi stanął oskarżony, wezwali na konsultacje medyków i stwierdzili coś zupełnie innego: jako kurację... ogolili mu głowę, po czym wysłali do prac przy budowie wileńskiego ratusza (Ragauskas 2012: 4).

W roku 1897 w odrodzeniowym czasopiśmie litewskim „Varpas” (Dzwon) został opublikowany artykuł litewskiego lekarza i działacza społecznego Mikalojusa Kuprevičiusa (1864-1932, pol. Mikołaj Kuprewicz) Lietuviški ligu vardai (Litewskie nazwy chorób), który konsekwentnie zachęcał do używania terminów pochodzenia litewskiego do nazywania chorób (także kołtuna). Co ciekawe, wśród przedstawionych przez niego nazw dwie do dziś nie mają swoich litewskich zamienników: kaltūnas 'kołtun' i rožé 'różyczka' (Zemlevičiūtè 2014: 182, 190).

Według jednego z najbardziej znanych litewsko-francuskich semiotyków, teoretyka literatury i językoznawcy Algirdasa J. Greimasa (1974: 39-40):

[...] kaltūnas, zapożyczenie z języków słowiańskich, służące do określenia choroby znanej jako Plica polonica, jest tylko zamiennikiem, który wypchnął z użycia litewskie słowo aitvaras (dial. atvaras).

Kołtun to nie tylko skołtunione włosy (syndrom zewnętrzny choroby), ale też wywołana przez aitvarasa choroba wewnętrzna obejmująca oprócz włosów także

14 W oryginale: tankiom kaulinèm šukom / ilgai tau kasas šukuos / stipriai supins, susegs / [...] / kad tik kaltūnas / neįsimestu, kad tik gyvybè / neišsisunktu, lašas po lašo [...].

15 Mając na myśli czasy Wielkiego Księstwa Litewskiego i Rzeczypospolitej Obojga Narodów, choć postrzeganie kołtuna jako ciężkiej choroby trwało na Litwie aż do końca XIX w. 
paznokcie i jelita ${ }^{16}$. W Litwie Pruskiej kaltūnas był nawet używany wymiennie $\mathrm{z}$ aitvaras, który nie tylko zabierał człowiekowi wszelkie dobra, ale mógł go zarazić kołtunem! (ibid.: 39) Innym synonimem aitvarasa jest velnias 'diabeł' ${ }^{17}$, któremu po śmierci muszą służyć wszyscy źli ludzie korzystający wcześniej z jego „usług” (Patackas, Žarskus 2013: 279). Aitvaras oznacza skrzata, chochlika, duszka zamieszkującego domostwo, a także serca gospodarzy ${ }^{18}$ i rozprzestrzeniającego się jak choroba. Jego obecność w domu mogła przynosić zarówno dobry, jak i zły los. W litewskich bajkach są opisy zakupu aitvarasa od diabła (inaczej Niemca) w zamian za duszę. Przeciwnie do panującej opinii aitvaras nie jest dobrym skrzatem, a złośliwym duchem odbierającym majątek albo apetyt. Aitvaras-kaltūnas, który atakuje przede wszystkim ludzi, może także być przeniesiony na konie, które ślepną i kuleją. Jednak inaczej niż w przypadku ludzi, których kaltūnas osłabia, kaltūniniai arkliai (dosł. kottunowe konie) stają się wyjątkowo silne, o mocy, która pozwala im na zmierzenie się z tajemną mocą aitvarasa (Greimas 1974: 42-43). Dlatego też przymocowana na progu domu końska podkowa miała moc chronienia domu (jego dobrobytu) przed aitvarasem-kottunem.

Tradycyjna kultura litewska znała różne techniki magiczne komunikowania się z kołtunem i jego leczenia ${ }^{19}$. Do jego odpędzania stosowano przykładowo formułę: Liga - lauk! Sveikata - į vidu! (Chorobo - wynoś się! Zdrowie - do środka!). Towarzyszył jej rytuał uderzania domowników po głowie poświęconymi gałązkami wierzbowymi, tuż po przyniesieniu ich z kościoła w Niedzielę Palmową (LUž: 153, wieś Żagary, pow. rosieński, zapis z 1938 r.). Innym symbolicznym sposobem służącym pozbywaniu się kołtuna było przelewanie wosku nad głową chorego i wypowiadanie zamowy: - Ka tu pili? - Votị su kaltūnu. - Pilk, kad jị išpiltum! (- Co tam lejesz? - To wrzód z kołtunem. - Lej i wylej wszystko!) (Greimas 1974: 41; LUž: 128, wieś Koleśniki, pow. święciański, zapis z 1928 r.). Rytuałowi odczyniającemu kołtuna podczas księżyca w nowiu (lit. gwar. jaunas mènulis 'młody księżyc') towarzyszy formuła: Tau ponaut, man karaliaut / man sveikata, tau pilnatis (Tobie pa-

16 Choć zdaniem A.J. Greimasa (1974: 40) to przykład najbardziej wątpliwy i niepotwierdzony.

17 Wyobrażenie aitvarasa jako 'diabła' potwierdza też tekst gwarowy z pow. poniewieskiego zapisany w okresie międzywojennym przez Helenę Szwejkowską (zob. Nitsch 1968: 368).

18 Także 'latawiec'. Aitvaras mógł przybierać m.in. postać kołtuna, ognia (iskra; ziejący ogniem kogut wywołujący pożary), złej bogini Apidėmė, która osiedlała się w porzuconych przez mieszkańców siedzibach (z powodu obecności aitvarasa) (Greimas 1974: 47, 1979: 90-92, także Razauskas 2008: 11-18).

19 Liczne relacje na temat kołtuna jako choroby i ludowych praktyk jego pozbywania się zarejestrowano w zbiorach archiwalnych Instytutu Języka Litewskiego w Wilnie (zob. http://lkiis.lki. lt/liaudies-tikejimu-kartoteka). Ramy tego artykułu nie pozwalają na obszerniejsze zaprezentowanie tych interesujących materiałów, zarchiwizowanych w postaci nagrań i rozpisanych tekstów, opatrzonych szczegółowymi informacjami o pochodzeniu źródeł. W przyszłości należałoby ten korpus tekstów folkloru poddać odrębnej analizie z perspektywy etnolingwistycznej czy etnologicznej. 
nowanie, dla mnie królowanie / dla mnie zdrowie, dla ciebie pełnia) (LUž: 257, wieś Puczkaryszki, pow. uciański, zapis z 1951 r.). Aby uchronić się przed kołtunem (też wrzodami i różyczką), stosowano formułę modlitewną, kierowaną do Najświętszej Marii Panny: Šventa Pana Marija, šaukiames mes in tavo šventų losketi [= malonę]. Ratavoji [= Gelbsti] visu svietu, ratavok mani, jaunu griešnykị [= nusidèjèlę], apguldyk vocị, kunigi, kaltūnų (Święta Panno Maryjo, wzywamy twojej świętej łaski. Ratuj cały świat, ratuj mnie, młodego grzesznika, ochroń przed wrzodami, różyczką, kołtunami) (LUž: 431, okolice Oran, lit. Varèna, 1928 r.).

Penetracje korpusowe ukierunkowane na obecność leksemu kaltũnas w zasobach współczesnego języka litewskiego nie przyniosły zbyt obfitych danych. Korzystałyśmy w pierwszej kolejności z elektronicznego systemu informacyjnego Lietuviu kalbos ištiekliu informacinè sistema (LKIIS), który skupia różne zasoby, e-słowniki i e-kartoteki. W zaktualizowanym Korpusie Współczesnego Języka Litewskiego (Dabartinés lietuviu kalbos tekstynas, DLKT), który powstał na bazie korpusu z lat 1998-2013 ${ }^{20}$, zarejestrowano 93194172 słowa z zakresu publicystyki, 27022058 literatury niefikcjonalnej, 21196089 - literatury fikcjonalnej, 15506670 - tekstów administracyjnych, 715176 - języka mówionego. Kaltūnas został potwierdzony tylko 13 razy, w tym było 7 użyć z tekstów literackich (m.in. $\mathrm{z}$ dwóch powieści przetłumaczonych z języka polskiego), 5 przykładów z tekstów publicystycznych, 1 potwierdzenie $\mathrm{z}$ antologii dowcipów.

Ze skąpo podawanych ilustracji wynika, że nazwa oznacza głównie 'zaniedbane, nieuczesane, skłębione, posklejane włosy', np.:

būtinai pasišluoju, tik pamečiau šukas, tai ị plaukus kaltūnas įsimetė... [oczywiście, sama zamiotę, tylko zgubiłam grzebień, dlatego kołtun się zadomowił we włosach...] (DLKT: Senojo Bokšto gyventojai (Mieszkańcy Starej Wieży), baśnie);

o iš moters belikęs šešèlis. Ant galvos - pilkšvu plaukų kaltūnas, po įdubusiomis akimis - juodi ratilai [a kobieta pozostawiła tylko cień. Na głowie - kołtun siwawych włosów, pod zapadłymi oczami - ciemne kręgi] (DLKT: N. Ikstena, Gyvenimas yra gyvenimas yra gyvenimas (Życie to życie to życie), powieść, Vilnius 2004);

Mano plauku pakulu kaltūnas tikrai negalejo patikti vaikus vedančioms ponioms [W rzeczywistości moje włosy z kołtunem jak pakuły nie mogły się spodobać paniom prowadzącym dzieci] (DLKT: L. Gutauskas, Daiktai (Rzeczy), powieść, Vilnius 2008);

traktatu gyd. H. Dar-Dobržickis galutinai ịrodè, kad kaltūnas ne liga, o antisanitarijos pasekmé [w traktacie dr H. Dar-Dobrzyckis ostatecznie udowod-

20 Zob. http://tekstynas.vdu.lt/tekstynas. 
nił, że kołtun nie jest chorobą, a rezultatem nieprzestrzegania zasad higieny] (DLKT: „Mokslas ir gyvenimas” (Nauka i Życie) 1995, tekst publicystyczny); (pa)liečiau rankom galvą. Didžiulis plaukų, lako ir šampano kaltūnas. O prie ausies vieniša sagele [dotknęłam ręką głowy. Wielki kołtun włosów, lakieru i szampana. A przy uchu samotny guzik] (DLKT: tłum. z polskiego, I. Sowa, Šviežiu aviečiu skonis (Smak świeżych malin), powieść, Vilnius 2004).

Dwukrotnie w DLKT odnotowano użycie połączenia kiaurasis kaltūnas jako terminu medycznego 'favus capillitis; rodzaj grzybicy skóry głowy' [dosł. kołtun, którego skutkiem jest rana („dziura”) w głowie] z ilustracją:

kiaurasis kaltūnas - kai prasiveria, tai ilgai negyja [kiedy już się przebije, to długo się nie goi] (subkorpus Terminologija (Terminologia), 2003).

Pojedynczym przykładem potwierdzone zostało użycie nazwy kaltūnas w odniesieniu do zniekształconych paznokci:

Nagu kaltūnas - stori sukumpę suskilę nagai [Kołtun paznokci - grube z naroślami, popękane paznokcie] (DLKT: Banginis prarijo lietuvį: nepaprasti lietuviu nuotykiai 1900-1940 metais: humoro antologija (Wieloryb połknął Litwina: niezwykłe przypadki Litwinów w latach 1900-1940: antologia humoru), sud. A. Ikamas, Vilnius 2012).

W danych korpusowych zarejestrowano również tylko jedną formę derywowaną kaltūnuotas:

Šalia šventyklos glaudèsi vienuolyno virtuvè, o joje kaltūnuotas, žvairakis žmogènas pjaustè ropes, ridikus [Do świątyni była przytulona kuchnia zakonna, a w niej kołtuniasty, zezowaty człowieczek kroił na kawałki rzepę, rzodkiewki] (DLKT: J. Ivanauskaitè, Sapnu nublokšti (Odtrąceni przez sny), powieść, Vilnius 2000).

Warto odnotować, że ani kaltūnas, ani derywaty nie pojawiają się w korpusie języka mówionego ${ }^{21}$.

Nazwa kaltūnas ma natomiast znacznie bogatszą dokumentację niż w korpusach w słownikach języka litewskiego, zwłaszcza w LKŽe, który rejestruje formy i znaczenia ustalone na podstawie wielu źródeł, zróżnicowanych gatunkowo, chro-

21 Opieramy to stwierdzenie na kwerendzie dwóch korpusów: języka mówionego (http://sakyti nistekstynas.vdu.lt/index.php) oraz współczesnego języka litewskiego (https://semantika.lt/Re sources/CorporaSearchDLKT). 
nologicznie i geograficznie. DLKŽ potwierdza ze współczesnej praktyki językowej dwa podstawowe znaczenia: 1) med. 'choroba (trichoma), której efektem jest zbity kłąb włosów na głowie, powstały wskutek brudu, niemycia i nieczesania włosów, połączony zwykle z wszawicą'; 2) pej. 'określenie włosów, używane zazwyczaj w l. mn.' (paralelne do pol. pot. postaci kołtuny 'rozczochrane i poplątane włosy'). DLKŽ notuje też derywaty: kaltūnius, -é, rzeczownik używany w r.m. i r.ż. jako pej. określenie 'człowieka zaniedbanego, o brudnych, skołtunionych włosach' i przymiotnik kaltūnúotas, -a 'skołtuniony(-a); kołtuniasty(-a)'. Zdecydowanie bogatszy zasób znaczeń i form odnotowuje wspomniany LKŽe, ilustrując użycia przykładami z literatury i folkloru litewskiego i wskazując na pokrewieństwo lit. leksemu kaltūnas z ros. колтун i pol. kołtun ${ }^{22}$. LKŽe jako podstawowe ujmuje trzy znaczenia: 1) 'choroba (Plica polonica)', 2) 'zbite, sklejone, sfilcowane, rozczochrane włosy (używane przede wszystkim w $1 \mathrm{~m}$. i z nacechowaniem pej.)' i 3) pej. 'zaniedbany, niechlujny człowiek'. Postać r.ż. kaltūnè oznacza ponadto żyjącego w Indonezji makaka czubatego (Macaca nigra), a forma lm. kaltūnai to także potoczna nazwa rośliny (pol. przelot pospolity, łac. Anthyllis vulneraria), zawdzięczającej swoją nazwę „kołtunowi” kwiatostanu. Przywołane użycia ze świata zoologii i botaniki są interesującymi przykładami wariantywności semantycznej nazwy kaltūnas, nieobecnej w polszczyźnie.

Kaltūnas jest komponentem licznych złożeń przymiotnikowych i rzeczownikowych, zróżnicowanych także regionalnie, np. kaltūngal̃vis, $-\dot{e}$ [kaltūnas + galva 'głowa'] 'o kimś, kto ma bardzo sfilcowane, skłębione włosy’; kaltūnnãgis, $-\dot{e}$ [kaltūnas + + nagas 'paznokieć'] 'mający(-a) zniekształcone paznokcie (paznokcie z naroślami)';

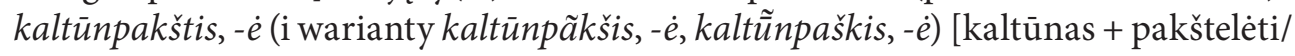
pakšèti 'pot. cmokać, cmoknąć'23] 'o kimś zaniedbanym, potarganym, z kołtunem na głowie'; kaltūnplaũkis, -e [kaltūnas + plaukas 'włos'] 'o kimś, kto ma potargane, skołtunione, sfilcowane włosy’; kaltũnvèle [kaltūnas + velti '1. filcować, pilśniować;

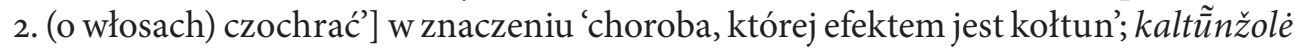
[kaltūnas + žolè 'zioło'] jako nazwa gwarowa rośliny 'tojeść rozesłana (Lysimachia nummularia)', por. pol. gwar. kołtunnik 'ziele, którego kępiastych korzeni używano w chorobie tzw. kołtuna' (SKarł II: 409).

O różnorodności form używanych w litewszczyźnie do nazywania mężczyzny czy kobiety z rozczochranymi i splątanymi, ale także długimi włosami niech świadczą chociażby następujące określenia rzeczownikowe: kaltũnius, - $\dot{e}$; kaltūnuõtis, $-\dot{e}$;

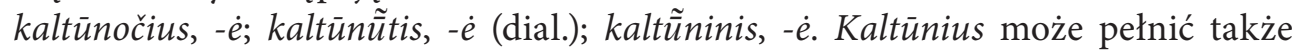

22 Wojciech Smoczyński (SEJL: 583) również opowiada się za zapożyczeniem słowiańskim, powołując się na pracę Jana Otrębskiego (1932: 22) i słownik Ernsta Fraenkla (LEW: 208, hasło: kalčỹs). Wywodzi postać kaltūnnas ze stbłr. ${ }^{*}$ koltunz i wkazuje na paralele z błr. kaŭtún, ukr. kovtún, pol. kołtun.

23 Pochodzenie drugiego członu złożenia jest niepewne, może należy brać pod uwagę dźwiękonaśladowcze $p a k \check{s}(t)$ 'kap, pac, cmok, także odgłos strzału'. 
funkcję przezwiska. Zkolei formy przymiotnikowe, np. kaltũninis, -é; kaltūnúotas, -a, również odnoszą się do 'osoby z potarganymi, rozczochranymi włosami (kołtunami), z kołtunem na głowie, ale także do człowieka chorego'.

Natomiast sam proces 'kołtunienia, powstawania kołtuna' oddają w języku litewskim w świetle danych LKŽe takie czasowniki, jak: kaltūnúoti (-úoja, -ãvo), prefigowane apkaltūnúoti, įsikaltūnúoti, išsikaltūnúoti. Postać werbalna susikaltūnúoti jest używana w znaczeniu przenośnym 'ciągnąć za włosy, kudły, kołtuny'. Sensy metaforyczne wyrażają też stosunkowo liczne frazeologizmy z komponentem kaltūnas, zarejestrowane w FŽe z różnych regionów Litwy (lokalizacja materiału jest podawana na końcu w nawiasie):

¿ kaltũ̃nq ịsivélti 'przyczepić się, żądać ślubu' (dosł. wplątać się w kołtun) (Kuršénai);

kaltũnais mainýtis 'bić się, szarpać się’ (dosł. wymieniać się kołtunami) (Kruopiai);

kaltũ̃nas nuẽ jo 'skończyły się troski’ (dosł. kołtun poszedł) (Bagótšilis);

kaltūnas nusliñko nuo širdiẽs 'skończyły się troski' (dosł. kołtun spadł z serca) (Vajasì̌skis);

kaltūnq nuravéti 'zbesztać' (dosł. wyrwać kołtun) (z pism Pranasa Treinysa); kaltũna ráuti 'besztać' (dosł. wyrywać kołtun) (z pism Pranasa Treinysa); kaltũñ ráuti nuo galvõs '1. ciągle besztać' (dosł. wyrywać kołtun z głowy) (Rimšẽ ); '2. ciągle prześladować, uciskać, męczyć' (Rimšẽ); kaltūna užsidéti ant galvõs 'ściągnąć na siebie biedę, kłopoty, zmartwienia' (dosł. założyć kołtun na głowę) (Rum̃̃šiškès, Garliavà);

kaltūnù sèdéti ant galvõs 'naprzykrzać się, znudzić się, mieć dość' (dosł. kołtunem siedzieć na głowie) (Panevèžỹs);

kaltūnùs nuráuti 'zbić, spuścić lanie' (dosł. wyrwać kołtuny) (Molétai);

voti lieti su kaltūnu 'obgadywać, plotkować' (dosł. wylewać wrzód z kołtunem) (Vakiniñkai).

W wyrażeniach porównawczych kaltūnas występuje rzadko, w słowniku porównań, dostępnym w systemie LKIIS ${ }^{24}$, odnotowano tylko jeden kontekst: Galva nešukuota visa susivélusi kaip kaltūnas [Głowa (= włosy) potargana, cała splątana jak kołtun] (Joniškis).

$\mathrm{W}$ świetle danych frazeologicznych i innych faktów systemowych w litewskiej konceptualizacji kołtun łączy się ze zjawiskami i cechami niepozytywnymi: biedą, zaniedbaniem, uciskiem, kłopotami, zmartwieniem, zmęczeniem, a nawet $\mathrm{z}$ bijatyką (szarpaniem za włosy).

24 Zob. http://lkiis.lki.lt/palyginimu (dostęp: 16 II 2020). 
Między konceptualizacją kołtuna odzwierciedloną w tekstach kultury polskiej i litewskiej oraz danych słownikowych zachodzą zbieżności i różnice. Łączy je:

1) postrzeganie kołtuna jako tajemniczej choroby wpisującej się w ludowy system wierzeń i rytuałów magicznych;

2) przeniesienie znaczenia $z$ choroby na niechlujną fryzurę (zbite $w$ kłąb, brudne, nieuczesane włosy); wyraźnie zaznaczająca się frekwencja formy lm. w pej. znaczeniu 'skłębione, sterczące włosy; kudły'.

Różnicuje natomiast:

1) w obu językach obok nazwy podstawowej występują liczne formy pochodne, niemniej zasób litewskiej leksyki odnoszącej się do badanego pojęcia jest w świetle faktów systemowych bardziej rozbudowany niż w polszczyźnie, obok derywatów rzeczownikowych i przymiotnikowych występują tu złożenia zróżnicowane regionalnie, czasowniki prefigowane, bardzo liczne frazeologizmy odzwierciedlające zniuansowanie znaczeń;

2) w obu językach dokonał się proces antropomorfizacji pojęcia i przeniesienia znaczenia: 'choroba' > 'człowiek', ale derywacja semantyczna przebiegała trochę inaczej w polszczyźnie i litewszczyźnie i inny element stanowił motywację przeniesienia. We współczesnym języku polskim kołtun to człowiek negatywnie wartościowany z powodu pewnych cech psychicznych 'zacofany, ograniczony intelektualnie, obłudny', natomiast w litewskim - człowiek postrzegany w wymiarze fizycznym 'brudny, zaniedbany, niechlujny'. Takie konotacje potwierdzają też wyrazy pochodne, które umacniają w polszczyźnie (por. kołtuński, kołtuństwo, kołtuneria) związek pojęcia z zacofaniem, fałszem, ograniczonymi horyzontami intelektualnymi, a w języku litewskim - z biedą, zaniedbaniem, zmartwieniem, kłopotami i zmęczeniem.

\section{Skróty}

błr. - białoruski; dial. - dialektalny; dosł. - dosłownie; fr. - francuski; gwar. - gwarowy; lit. - litewski; łac. - łaciński; med. - medyczny; pej. - pejoratywny; pol. - polski; pot. - potoczny; psł. - prasłowiański; ros. - rosyjski; stbłr. - starobiałoruski; ukr. - ukraiński

\section{Literatura}

Adelung J.Ch., 1811, Grammatisch-kritisches Wörterbuch der hochdeutschen Mundart, [on-line:] http://lexika.digitale-sammlungen.de/adelung/online/angebot.

ANDriušis A., RimavičIENĖ A., 2006, Institucine medicinos mokslu pradžia Vilniaus universitete: nuo Vilniaus medicinos mokyklos iki Collegium Medicum (1775-1781), [w:] A. Andriušis (red.), Vilniaus medicinos istorijos almanachas, t. 2, Vilnius, s. 17-25.

BARTMIŃski J., 2006a, O pojęciu językowego obrazu świata, [w:] idem, Językowe podstawy obrazu świata, Lublin, s. 11-21. 
BARTMIŃski J., 2006b, Punkt widzenia, perspektywa, językowy obraz świata, [w:] idem, Językowe podstawy obrazu świata, Lublin, s. 76-88. Pierwodruk w: J. Bartmiński (red.), Językowy obraz świata, Lublin 1990, s. 109-121.

BARTMIŃsKi J., 2009, Czy możemy wyzwolić się ze stereotypów? Stereotypy a wzory kultury, [w:] idem, Stereotypy mieszkaja w języku. Studia etnolingwistyczne, Lublin, s. 106-111.

Bartmiński J., Niebrzegowska-Bartmińska S., 2006, Dynamika kategorii punktu widzenia w języku, tekście, dyskursie, [w:] J. Bartmiński, Językowe podstawy obrazu świata, Lublin, s. 106-130. Pierwodruk w: J. Bartmiński, S. Niebrzegowska-Bartmińska, R. Nycz (red.), Punkt widzenia w jezzyku i w kulturze, Lublin 2004, s. 321-358.

Brodski J., 200o, Divertimento litewskie, [w:] idem, Tym tylko byłem. Wybór wierszy, tłum. S. Barańczak, Kraków, s. 51-54.

DLKT: Dabartinés lietuvių kalbos tekstynas (Korpus Współczesnego Języka Litewskiego), [on-line:] https://semantika.lt/Resources/CorporaSearchDLKT.

DLKŽ: Dabartinés lietuvių kalbos žodynas, wydanie elektroniczne, [on-line:] http://lkiis.lki. lt/dabartinis.

DW: J. Grimm, W. Grimm, Deutsches Wörterbuch, I-XXXII, Leipzig 1854-1961, [on-line:] http://woerterbuchnetz.de/cgi-bin/WBNetz/wbgui_py?sigle=DWB. http://woerterbuch netz.de/cgi-bin/WBNetz/wbgui_py?sigle=DWB\&mode=Vernetzung\&lemid=GW13121\# XGW13121.

Engelking A., 200o, Klątwa. Rzecz o ludowej magii słowa, Wrocław.

FŽE: Frazeologijos žodynas, [on-line:] http://lkiis.lki.lt/frazeologizmu.

Gloger Z., 1978, Kołtun, [w:] idem, Encyklopedia staropolska ilustrowana, wstęp J. Krzyżanowski, t. 3, Warszawa, s. 63-64 [1900-1903].

Greimas A.J., 1974, Kaukai ir aitvarai. Antroji dalis: Aitvaras, „Metmenys. Jaunosios kartos kultūros žurnalas" nr 28, s. 22-67.

Greimas A.J., 1979, Apie dievus ir žmones: lietuvių mitologijos studijos, Chicago.

Grimm J., 1835, Wickelt der nachtalb, [w:] idem, Deutsche Mythologie, Göttingen, s. 262, [on-line:] https://books.google.de/books?id=IutAAAAAcAAJ\&pg=PA262\&lpg=PA262 $\& \mathrm{dq}=\% 22$ wickelt+der+nachtalb\%22\&source=bl\&ots=a3HKpinB-w\&sig=_8LlswiKb_4U W5prVycF6X26UNY\&hl=de\&sa=X\&ved=oahUKEwj9xeKWjJ_cAhVGQhoKHUfjC1 gQ6AEIKjAB.

K3Kuj: O. Kolberg, Dzieła wszystkie, t. 3: Kujawy, cz. 1, Wrocław - Poznań 1962 [1867].

K11Poz3: O. Kolberg, Dzieła wszystkie, t. 11: Wielkie Księstwo Poznańskie, cz. 3, Wrocław - Poznań 1982 [1877].

LEW: E. Fraenkel, Litauisches etymologisches Wörterbuch, t. I-II, przy współpr. A. Słupski, E. Hofmann, E. Tangl, Heidelberg - Göttingen 1955-1965.

LKIIS: Lietuviu kalbos ištiekliu informacinè sistema (System Informacyjny Zasobów Języka Litewskiego), [on-line:] http://lkiis.lki.lt.

LKŽE: G. Naktinienè, J. Paulauskas, R. Petrokienè, Z. Šimėnaitè, V. Vitkauskas, J. Zabarskaitè (red.), Lietuvių kalbos žodynas, wyd. 2 elektroniczne, t. 1-20, Vilnius 2013 [1941-2002].

LUž: D. Vaitkevičienè (red.), Lietuvių užkalbejimai: gydymo formulès. Lithuanian Verbal Healing Charms, Vilnius 2008.

ŁopatyńsKa H.M., 2013. Koltun pilnie poszukiwany, Muzeum Etnograficzne im. Marii Znamierowskiej-Prüfferowej w Toruniu, [on-line:] http://etnomuzeum.pl/koltun-pilnieposzukiwany/.

Łotman J., Uspienski B., 1977, O semiotycznym mechanizmie kultury, [w:] E. Janus, R.M. Mayenowa (wybór i oprac.), Semiotyka kultury, Warszawa, s. 147-170. 
MarCZewska M., 2012, Ja cię zamawiam, ja cię wypędzam... Choroba. Studium językowo-kulturowe, Kielce.

MiežUtAVIČIŪtė V., 1991, Kaltūno etiologijos tyrinèjimai Vilniaus medicinos draugijos veikloje, „Medicina” nr 7-8 (27), s. 88-89.

Miliauskaitė N., 1999, ${ }^{* * *}$ ateina gerokai po vidurnakčio..., [w:] eadem, Sielos labirintas, Vilnius, s. 446-447.

NAGóRкo A., 2004, Metody kontrastywne a etnolingwistyka (lingwistyka kulturowa), [w:] É. Fórián (red.), Wielokulturowość, tożsamość narodowa, mniejszości na Wegrzech i w Polsce. Jezzk - literatura - kultura, Debreczyn, s. 23-33.

Narodowy Korpus Języka Polskiego, praca zbiorowa, red. A. Przepiórkowski, M. Bańko, R.L. Górski, B. Lewandowska-Tomaszczyk, Warszawa 2012.

NitsCH K., 1968, Wybór polskich tekstów gwarowych, wyd. 3, Warszawa.

NKJP: Narodowy Korpus Języka Polskiego, [on-line:] nkjp.pl.

Отrе̨вSк J., 1932, Wschodniolitewskie narzecze twereckie, cz. 3: Zapożyczenia słowiańskie, Kraków.

Patackas A., Žarskus A., 2013, Virsmų knyga. Vestuviu virsmas, gimties virsmas, mirties virsmas, wyd. 2, Kaunas.

PWJK: J. Bartmiński, S. Niebrzegowska-Bartmińska, R. Nycz (red.), Punkt widzenia w języku iw kulturze, Lublin 2004.

PWTD: J. Bartmiński, S. Niebrzegowska-Bartmińska, R. Nycz (red.), Punkt widzenia w tekście i $w$ dyskursie, Lublin 2004.

RagausKas A., 2012, Lietuviška kaltūno „ligos” istorija, Orbis Lituaniae, [on-line:] http://m. ldkistorija.lt/index.php/istoriniai-faktai/lietuviska-kaltuno-ligos-istoija/546.

RAZAUSKAS D., 2008, Iš baltų mitinio vaizdyno juodraščių: Aitvaras, „Liaudies kultūra” nr 6 (123), s. 8-25, [on-line:] http://tautosmenta.lt/wp-content/uploads/2013/12/Razauskas_ Dainius/Razauskas_BMVJ_LK_2008_6.pdf.

Römer M., 2017, Dzienniki, t. 1: 1911-1913, wybór J. Sienkiewicz, red. A. Knyt, Warszawa.

SCHWENCK K., 1838, Wörterbuch der deutschen Sprache in Beziehung auf Abstammung und Begriffsbildung, Frankfurt am Main, [on-line:] http://reader.digitale-sammlungen.de/de/ fs1/object/display/bsb10584363_00005.html.

SEBAń: A. Bańkowski, Etymologiczny słownik języka polskiego, t. 1-2, Warszawa 2000.

SEBor: W. Boryś, Słownik etymologiczny języka polskiego, Kraków 2005.

SEBR: A. Brückner, Słownik etymologiczny języka polskiego, Warszawa 1970 [1927].

SEJL: W. Smoczyński, Słownik etymologiczny języka litewskiego, współpr. red. M. Osłon, wyd. 2, popr. i znacznie rozsz., na prawach rękopisu (data utworzenia pliku: 26 I 2020), [on-line:] https://rromanes.org/pub/alii/Smoczy\%C5\%84ski\%2oW.\%20S\%C5\%82ownik \%2oetymologiczny\%2oj\%C4\%99zyka\%2olitewskiego.pdf.

SESŁ: F. Sławski, Słownik etymologiczny języka polskiego, t. I-V, Kraków 1952-1982.

SF: S. Skorupka, Słownik frazeologiczny języka polskiego, t. I-II, Warszawa 1967-1968.

SKarŁ: J. Karłowicz, Słownik gwar polskich, t. I-VI (t. IV-VI do druku przygot. J. Łoś), Kraków 1900-1911.

SN: K. Rymut, Słownik nazwisk współcześnie w Polsce używanych, t. 1-10, Kraków 1992-1994.

Tokarczuk O., 2018, Opowiadania bizarne, Kraków.

USJP: S. Dubisz (red.), Uniwersalny słownik języka polskiego, t. I-IV, Warszawa 2003.

Widacka H., 2008, Plica polonica czyli kołtun polski, Muzeum Pałacu Króla Jana III w Wilanowie, [on-line:] https://www.wilanow-palac.pl/plica_polonica_czyli_koltun_polski. html. 
Wielki słownik języka polskiego PAN. Geneza, koncepcja, zasady opracowania, praca zbiorowa, red. P. Żmigrodzki, M. Bańko, B. Batko-Tokarz, J. Bobrowski, A. Czelakowska, M. Grochowski, R. Przybylska, J. Waniakowa, K. Węgrzynek, Kraków 2018.

WSJP PAN: P. Żmigrodzki (red.), Wielki słownik języka polskiego PAN, [on-line:] wsjp.pl.

ZemLevičıūtė P., 2014, Gydytojas Mikalojus Kuprevičius lietuviu medicinos terminologijos baruose. Mikalojaus Kuprevičiaus 150-osioms gimimo metinèms, „Lituanistica” 60, nr 3, s. 180-197, [on-line:] https://doi.org/10.60o1/lituanistica.v6oi3.2985.

ŻEgleń U., 2000, Wprowadzenie do semiotyki teoretycznej i semiotyki kultury, Toruń.

\section{Semantic Variations of the Concept of kołtun 'Polish Plait' in Selected Text of Polish and Lithuanian Cultures Summary}

The paper discusses semantic changes and stylistic derivation of the cultural concept of koltun 'Polish plait' (Plica polonica) in Polish and Lithuanian. Although today it is impossible to meet a person with a kottun on their head, the concept itself, as an element of socially established knowledge of the world, has survived and is still used in various discourses (ranging from dialectal texts and folklore, belles-lettres and journalistic writing, to contemporary Internet messages), to communicate different meanings, both literal and metaphorical.

There are similarities and differences between the conceptualizations of koltun in texts of Polish and Lithuanian cultures. The unifying element is the perception of koltun as a formation of entangled hair or a mysterious disease that is inscribed into the folk system of beliefs and magical rituals. On the other hand, what sets the analysed concept apart in the two languages, is a much richer resource of folk and colloquial forms (compounds, hybrid words, phrasemes) in Lithuanian, and in addition, the lack of negative evaluation of kottun in Lithuanian, whereas in Polish the word is often used to describe a backward, small-minded person. 